\title{
A framework for refining soil microbial indices as bioindicators during decomposition of various organic residues in a sandy loam soil
}

\author{
Sandeep Sharma*, Jatinder Kaur, H. S. Thind, Yadvinder Singh, Neha Sharma and \\ Kirandip
}

Department of Soil Science, Punjab Agricultural University, Ludhiana-141004 (Punjab), INDIA

*Corresponding author. E-mail: sandyagro@rediffmail.com

Received: March 11, 2015; Revised received: July 12, 2015; Accepted: September 6, 2015

\begin{abstract}
Assessment of soil quality is an invaluable tool in determining the sustainability and environmental impact of agricultural ecosystems. Soil microbial indices like microbial biomass and microbial activity are important criteria for the determination of soil quality. Laboratory incubation study was undertaken to examine the influence of eight crop residues widely varying in biochemical composition on the periodic changes in important soil microbial indices $\left\{\left(\right.\right.$ microbial (Cmic: Corg), metabolic $\left(\mathrm{qCO}_{2}\right)$, carbon mineralization $(\mathrm{qC})$ and microbial biomass change rate ( $\mathrm{qM}$ ) quotients)\} at 28 days and 63 days after incubation (DAI) in a sandy loam soil. A. sativa amended soil showed maximum soil respiration rate $\left(14.23 \mathrm{mg} \mathrm{CO}_{2}-\mathrm{C} \mathrm{g}^{-1}\right.$ soil day $\left.{ }^{-1}\right)$ whereas $T$. aestivum amended soil showed maximum microbial biomass $C(790 \mu \mathrm{g} / \mathrm{g})$. The metabolic quotient among different crop residues ranged from 11.1 to $19.8 \mu \mathrm{g}$ $\mathrm{CO}_{2}-\mathrm{C} \mu \mathrm{g}$-biomass- $\mathrm{C}^{-1} \mathrm{~h}^{-1}$ at 63 DAl. The results indicate that incorporation of different crop residues has positive effect on microbial flora and their activity. Microbial quotient (Cmic:Corg) was significantly positively correlated with microbial biomass carbon (MBC), qC and qM. The study suggests that the biochemical composition of different crop residues seems to be of better option for long term sustainable crop production with maintenance of soil quality in a sandy loam soil.
\end{abstract}

Keywords: Crop residues, Microbial biomass, Microbial indices, Soil quality

\section{INTRODUCTION}

Soil and crop management practices such as cultivation, crop residue production, residue management and fertilization exert a considerable influence on the level of organic matter over time (Campbell et al., 1992). The organic matter plays a key role in determining soil health, which is defined as the soil's capacity to maintain environmental functions and biological productivity (Bini et al., 2013). It is directly related to different physical, chemical and biological soil properties ( Smith et al., 2000). To circumvent the loss of the organic matter, amendment using crop residue has been regularly being attempted (Bouajila and Sanaa, 2011). The soils amended with crop residues increase the supply of carbonaceous materials as an energy source for the living microorganisms and the dead microbial biomass provide the substrate (Mengel, 1996) leading to a series of biological transformations. The decomposition of crop residues in soil and their carbon and nitrogen mineralization depends on the composition of residues which transforms into $\mathrm{CO}_{2}$, microbial material and relatively stable humus components (Heal et al., 1997). It has been established that more dynamic characteristics such as microbial biomass, soil respiration and soil enzyme activity respond more quickly to changes in crop management practices or environmental conditions (Brookes, 1995). Soil microbial biomass (SMB) plays a key role in controlling the nutrient cycling and energy flow in soil ecosystems (Heal et al., 1997). It represents the living fraction of soil organic matter which is responsible for organic matter and residue decomposition (Sparling and Ross, 1993). Soil respiration rate, Cmic:Corg and $\mathrm{qCO}_{2}$ quotients directly reflects soil microbial activities, and are affected by the eco-environmental changes (Alvarez et al., 1995). The Cmic:Corg and $\mathrm{qCO}_{2}$ quotients was calculated as ratio of microbial biomass carbon (MBC) to soil organic carbon (SOC) and rate of basal respiration per unit of $\mathrm{MBC}$, respectively and these act as indicator of ecosystem disturbance and development (Anderson and Domsch, 1989). The $\mathrm{qCO}_{2}$ has valuable application as a relative measure of how efficiently the soil microbial biomass is utilizing $\mathrm{C}$ resources and the degree of substrate limitation for soil microbes (Wardle and Ghani, 1995; Dilly and Munch, 1998) and expresses the metabolic effectiveness of soil microbial communities (Saviozzi et al., 2002). The qM expresses the fraction of total organic carbon mineralized during incubation peroid (Pinzari et al., 1999). The $\mathrm{qC}$ expresses the daily enrichment or loss of soil microbial C (Anderson and Domsch, 1990).

During the last few decades, researchers have identified different crop residues with have variable biochemical 
composition having functional significance in the turnover of soil organic content (Lehtinen et al., 2014; Pandiaraj et al., 2015). So, knowledge on soil microbial indices and the mineralization of crop residues added to the soil is of utmost importance to address soil management practices to maintain soil quality. Therefore, soil microbial indices can be used as a measure to provide immediate and accurate information about changes occurring in soil during decomposition of different crop residues. The objective of the present research was to evaluate the dynamic changes in soil microbial indices that have been amended with different crop residues.

\section{MATERIALS AND METHODS}

Soil description: Laboratory incubation study was conducted on a sandy loam soil (Typic Ustipsamment) collected from experimental farm of the Punjab Agricultural University, Ludhiana $\left(30^{\circ} 56^{\prime} \mathrm{N}, 75^{\circ} 52^{\prime} \mathrm{E}\right.$, $247 \mathrm{~m}$ above mean sea level) in the Indo-Gangetic plains of north western India. Soil samples $(0-0.15 \mathrm{~m}$ depth) collected randomly from 8 locations within 0.4 ha field were thoroughly mixed to make a bulk sample of approximately $50 \mathrm{~kg}$. The bulk soil sample was partially air dried, sieved through $2 \mathrm{~mm}$ sieve and then cleaned manually to remove the visible crop residues and pebbles. The soil was then brought to field capacity moisture condition $(20 \% \mathrm{w} / \mathrm{w})$ and stored in polythene bags at room temperature $\left(19-20^{\circ} \mathrm{C}\right)$ for 10 days to stabilize the biological activity of the soil. The initial soil characteristics of experimental soil were $8.1 \mathrm{pH}$ (1:2 soil/water suspension), $0.38 \mathrm{dS} \mathrm{m}^{-1}$ electrical conductivity, $4.10 \mathrm{~g} \mathrm{~kg}^{-1}$ organic carbon (Walkley and Black, 1934), $9.72 \mathrm{mg} \mathrm{kg}{ }^{-1} \mathrm{KMnO}_{4}$-oxidizable $\mathrm{N}$ (Subbiah and Asija, 1956) , $3.13 \mathrm{mg} \mathrm{kg}^{-1}$ Olsen P (Olsen et al., 1954) and $31 \mathrm{mg} \mathrm{kg}^{-1} \mathrm{NH}_{4} \mathrm{OAc}-\mathrm{K}$ (using Elico 368 Flame photometer).

Treatments and experimental procedure: The study was conducted to measure the soil microbial indices at 28 and 63 days of incubation of soil with eight different plant residues viz., Lens culinaris, Avena sativa, Zea mays, Oryza sativa, Saccharum officinarum, Triticum aestivum, Brassica juncea, Hordeum vulgarae differing in $\mathrm{C} / \mathrm{N}$ ratio and chemical composition. All the plant residues were dried at $60 \pm 2^{\circ} \mathrm{C}$, finely ground $(<1 \mathrm{~mm})$ and stored in plastic bags before their use in the study as well as for the chemical analysis. A known weight of soil (550 g, dry weight basis) was weighed and transferred to one liter size polypropylene pots $(9 \mathrm{~cm}$ internal diameter and $10 \mathrm{~cm}$ long). The soil was then moistened using distilled water to bring it to field capacity. To these pots, $5.5 \mathrm{~g}$ ( $1 \%$ dry weight basis) each of the organic residue was added and the contents were uniformly mixed into soil. The base of the pot was tapped firmly to allow the contents to settle to a bulk density of $1.2 \mathrm{~g} \mathrm{~cm}^{-3}$. Soil sample without crop residue was also included as a control treatment. The treatments had three replications and the pots were arranged in a completely randomized block design. The treated pots were incubated at $30^{\circ} \mathrm{C}$ for 63 days and moist air was continuously circulated in the incubator.

Plant analysis: The total $\mathrm{C}$ and total $\mathrm{N}$ of the plant residues were determined from finely ground subsamples by dry combustion with Vario EL CHN elemental analyser (Heraeus Elementor EL, Hanau, Germany). The plasma atomic emission spectrometer (ICAP -AES) was used to carry out the micronutrients analysis of crop residues.

Biological analysis: Microbial biomass carbon (MBC) was measured by the chloroform fumigation extraction method (Vance et al., 1987). Two portions of moist soil (20 g oven-dry soil) were weighed, the first one (non-fumigated) was immediately extracted with $80 \mathrm{ml}$ of $0.5 \mathrm{M} \mathrm{K}_{2} \mathrm{SO}_{4}$ after orbital shaking for 30 minutes and then filtering through Whatman no. 42. The second portion was fumigated for 24 hours with ethanol-free $\mathrm{CHCl}_{3}$ and then extracted as described above. Extractable organic $\mathrm{C}$ in soil extracts was analyzed by dichromate digestion. Biomass $\mathrm{C}$ was estimated as: Biomass $\mathrm{C}=2.64 \mathrm{Ec}$, where $\mathrm{Ec}$ is the difference of $\mathrm{K}_{2} \mathrm{SO}_{4}$ extractable $\mathrm{C}$ between fumigated and unfumigated soils. Basal soil respiration (BSR) of the samples were determined by trapping the evolved $\mathrm{CO}_{2}$ in $\mathrm{NaOH}$ and the residual $\mathrm{NaOH}$ was then back titrated with $\mathrm{HCl}$ (Alef, 1995). Twenty gram soil was accurately weighed and taken in each incubation flask. Ten $\mathrm{ml}$ of $0.1 \mathrm{M} \mathrm{NaOH}$ was pipetted into a vial and the same was inserted into the flask. Thereafter the mouth of the flask was closed with airtight cork. Same procedure was followed for blank with no soil. The sample as well as the blank flask was incubated at $30^{\circ} \mathrm{C}$ for 7 days. After incubation period, vial containing $\mathrm{NaOH}$ solution was taken out of the flask and the contents were quantitatively transferred to a $50 \mathrm{ml}$ conical flask. Then two-three drops of phenolphthalein indicator solution were added to $\mathrm{NaOH}$, which was then titrated with $0.1 \mathrm{M} \mathrm{HCl}$. The $\mathrm{CO}_{2}$ production was calculated with the formula provided by Anderson (1982). Soil respiration measurements are reported as: (1) respiration per unit of soil weight and time (basal respiration); (2) respiration per unit of biomass $\mathrm{C}$ and time (specific respiration or $\left.\mathrm{qCO}_{2}\right)$ (Badia and Marti, 2003). Specific respiration (Santruckova and Straskraba, 1991), called metabolic quotient of $\mathrm{CO}_{2}\left(\mathrm{qCO}_{2}\right)$, represents the $\mathrm{CO}_{2}$ production per unit biomass and unit time ( $\mu \mathrm{g} \mathrm{CO}_{2}-\mathrm{C} \mu$ g-biomass- $\mathrm{C}^{-1} \mathrm{~h}^{-1}$ ) (Anderson and Domsch, 1990).

$\mathrm{qM}=\mu \mathrm{g}$ C- $\mathrm{CO}_{2}$ cumulative $\mu \mathrm{g}$ total organic carbon $^{-1}$ (TOC) (Pinzari et al., 1999);

$\mathrm{qC}=\left(\left(\mu \mathrm{g} \mathrm{Cmict}_{1}-\mu \mathrm{g}\right.\right.$ Cmict $\left.\left._{2}\right) / \mu \mathrm{g} \mathrm{Cmict}_{1} /\left(\mathrm{t}_{2}-\mathrm{t}_{1}\right)\right)$

$\mathrm{qC}$ is calculated as reported by Anderson and Domsch (1990) for qD.

Statistical analysis: Analysis of variance (ANOVA) was carried out using IRRISTAT version 5.0. Least significance difference (LSD) at a 0.05 level of 
Table 1. Micronutrients, total carbon, nitrogen and $\mathrm{C} / \mathrm{N}$ ratio of different crop residues.

\begin{tabular}{cccccccc}
\hline & \multicolumn{3}{c}{ Micronutrient content (mg/ka) } & \multicolumn{3}{c}{ Content (\%) } \\
\hline Crop residues & $\mathrm{Cu}$ & $\mathrm{Fe}$ & $\mathrm{Mn}$ & $\mathrm{Zn}$ & $\mathrm{C}$ & $\mathrm{N}$ & $\mathrm{C} / \mathrm{N}$ \\
Oat (A. sativa) & 17.1 & 138.7 & 26.4 & 17.5 & 42.0 & 1.32 & 31.8 \\
Maize (Z. mays) & 24.2 & 136.4 & 31.4 & 25.5 & 38.2 & 0.62 & 61.6 \\
Rice straw (O. sativa) & 1.9 & 217.5 & 215.7 & 42.0 & 38.3 & 0.81 & 47.3 \\
Wheat straw (T. aestivum) & 16.9 & 194.7 & 27.8 & 15.0 & 42.0 & 0.40 & 105.0 \\
Barley (H. vulgarae) & 30.0 & 292.0 & 44.3 & 96.0 & 35.6 & 0.71 & 50.1 \\
Lentil (L. culinaris) & 4.7 & 543.5 & 64.6 & 23.2 & 34.1 & 1.71 & 19.9 \\
Sugarcane trash (S. officinarum) & 64.6 & 568.5 & 52.6 & 40.4 & 37.3 & 0.91 & 41.0 \\
Mustard (B. juncea) & 25.1 & 221.0 & 24.7 & 18.1 & 40.5 & 1.18 & 34.3 \\
\hline
\end{tabular}

Table 2 . Effect of different crop residues on soil respiration $\left(\mathrm{mg} \mathrm{CO}_{2}-\mathrm{C} \mathrm{g}^{-1}\right.$ soil day $\left.^{-1}\right)$.

\begin{tabular}{ccccccccc}
\hline S.N. & Treatments & \multicolumn{1}{c}{ Days } \\
\hline & Days & 3 & 7 & 14 & 21 & 28 & 42 & 63 \\
1 & Control & 9.53 & 8.95 & 9.97 & 7.11 & 6.75 & 6.67 & 6.53 \\
2 & A. sativa & 12.98 & 14.23 & 13.20 & 10.85 & 10.05 & 10.12 & 9.75 \\
3 & Z. mays & 13.13 & 13.79 & 12.76 & 10.56 & 10.34 & 10.27 & 9.97 \\
4 & O. sativa & 13.05 & 13.57 & 12.98 & 10.93 & 10.34 & 10.34 & 9.90 \\
5 & T. aestivum & 12.39 & 13.57 & 12.69 & 10.41 & 10.12 & 10.05 & 10.05 \\
6 & H. vulgarae & 11.81 & 13.64 & 12.69 & 10.34 & 10.34 & 10.34 & 10.05 \\
7 & S. officinarum & 12.76 & 13.71 & 12.32 & 10.85 & 10.49 & 10.34 & 9.75 \\
8 & L. culinaris & 12.91 & 13.93 & 13.20 & 10.41 & 10.41 & 10.63 & 9.97 \\
9 & B. juncea & 11.37 & 13.86 & 13.49 & 10.93 & 10.41 & 10.27 & 9.97 \\
& LSD (0.05) & 0.715 & 0.715 & 0.758 & 0.508 & 0.465 & 0.391 & 0.429 \\
\hline
\end{tabular}

Table 3. Effect of different crop residues on cumulated soil respiration $\left(\mathrm{mg} \mathrm{CO}_{2}-\mathrm{C} \mathrm{g}^{-1}\right.$ soil day $\left.{ }^{-1}\right)$.

\begin{tabular}{|c|c|c|c|c|c|c|c|}
\hline S.N. & Treatments & \multicolumn{6}{|c|}{ Days } \\
\hline & & 7 & 14 & 21 & 28 & 42 & 63 \\
\hline 1 & Control & 18.5 & 28.5 & 35.6 & 42.3 & 49.0 & 55.5 \\
\hline 2 & A. sativa & 27.2 & 40.4 & 51.3 & 61.3 & 71.4 & 81.2 \\
\hline 3 & Z. mays & 26.9 & 39.7 & 50.2 & 60.6 & 70.8 & 80.8 \\
\hline 4 & O. sativa & 26.6 & 39.6 & 50.5 & 60.9 & 71.2 & 81.1 \\
\hline 5 & T. aestivum & 26.0 & 38.6 & 49.1 & 59.2 & 69.2 & 79.3 \\
\hline 6 & H. vulgarae & 25.4 & 38.1 & 48.5 & 58.8 & 69.2 & 79.2 \\
\hline 7 & S. officinarum & 26.5 & 38.8 & 49.6 & 60.1 & 70.5 & 80.2 \\
\hline 8 & L. culinaris & 26.8 & 40.0 & 50.5 & 60.9 & 71.5 & 81.5 \\
\hline 9 & B. juncea & 25.2 & 38.7 & 49.6 & 60.1 & 70.3 & 80.3 \\
\hline & $\operatorname{LSD}(0.05)$ & 1.06 & 1.46 & 1.39 & 1.46 & 1.62 & 1.73 \\
\hline
\end{tabular}

probability was used to test the significance of differences among treatment means.

\section{RESULTS}

The chemical compositions of the different crop residues studied are summarized in table 1 . The $\mathrm{C}$ content ranged from $34.1 \%$ (L. Culinaris) to $42.0 \%$ (A. sativa. and T. aestivum), and the $\mathrm{N}$ contents ranged from 0.40 $\%$ (T. aestivum) to $1.71 \%$ (L. culinaris.), resulting in $\mathrm{C} / \mathrm{N}$ ratios ranging from 19.9 (L. culinaris) to 105 (T. aestivum).

Soil respiration: The effect of various crop residues on microbial respiration after residue incorporation is shown in table 2 . The respiration rate was lowest in unamended soil throughout the experiment. In treated soils, the respiration rate peaked on day 7 and then decreased sharply until day 21 after which remained stable until day 63. The respiration rate on day 7 was highest in the soil with $A$. sativa residue with $14.23 \mathrm{mg}$ $\mathrm{CO}_{2}-\mathrm{C} \mathrm{g}^{-1}$ soil day ${ }^{-1}$ and lowest in the unamended soil with $8.95 \mathrm{mg} \mathrm{CO}_{2}-\mathrm{C} \mathrm{g}^{-1}$ soil day ${ }^{-1}$. Cumulative respiration on day 7 was lowest in the unamended control soil, and ranged between 25.2 to $27.2 \mathrm{mg} \mathrm{CO}_{2}-\mathrm{C} \mathrm{g}^{-1}$ soil day $^{-1}$ in the residue amended soils, being highest in soil with $A$. sativa and lowest with $B$. juncea residues (Table 3). The patterns of $\mathrm{CO}_{2}-\mathrm{C}$ evolution against days for the soil treated with various plant residues were similar. Results showed that, in general, the amount of $\mathrm{CO}_{2}-\mathrm{C}$ initially released rapidly during the first 7 days followed by a more slow evolution during the rest of incubation period. The cumulative amount of $\mathrm{CO}_{2}-\mathrm{C}$ released was significantly higher in all the plant residue treated soils compared to the control 
Table 4. Pearson correlation coefficients (r) between soil microbial quotients, microbial biomass carbon, organic carbon (OC) and soil respiration after 28 days.

\begin{tabular}{ccccccccc}
\hline & Micro Q & Meta Q & $\mathbf{q M}$ & $\mathbf{q C}$ & $\mathbf{M B C}$ & $\mathbf{O C}$ & Res & Cum-Res \\
\hline Mirco Q & 1 & -.746 & $.700^{* *}$ & $.879^{* *}$ & $.910^{* *}$ & .223 & .484 & .469 \\
Meta Q & & 1 & -.320 & -.674 & -.695 & -.143 & -.247 & -.201 \\
qM & & & 1 & 1.571 & .555 & .137 & $.667^{*}$ & .584 \\
qC & & & & 1 & $.999^{* *}$ & .624 & $.716^{*}$ & $.741^{*}$ \\
MBC & & & & & 1 & .593 & $.678^{*}$ & $.704^{*}$ \\
OC & & & & & & 1 & $.807^{* *}$ & $.870^{* *}$ \\
Res & & & & & & & & \\
Cum-Res & & & & & & & & $.983^{* *}$ \\
\hline
\end{tabular}

Table 5. Pearson correlation coefficients (r) between soil microbial quotients, microbial biomass carbon, organic carbon (OC) and soil respiration after 63 days.

\begin{tabular}{ccccccccc}
\hline & Micro Q & Meta Q & $\mathbf{q M}$ & $\mathbf{q C}$ & $\mathbf{M B C}$ & $\mathbf{O C}$ & Res & Cum-Res \\
\hline Micro Q & 1 & $-.681^{*}$ & $.731^{*}$ & $.858^{* *}$ & $.891^{* *}$ & -.320 & .439 & .432 \\
Meta Q & & 1 & -.197 & -.431 & -.536 & .419 & .162 & .150 \\
qM & & & 1 & .630 & .567 & -.347 & $.711^{*}$ & $.683^{*}$ \\
qC & & & & 1 & $.988^{* *}$ & .201 & $.730^{*}$ & $.743^{*}$ \\
MBC & & & & & 1 & .139 & .617 & .632 \\
OC & & & & & & 1 & .401 & .433 \\
Res & & & & & & & 1 & $.986^{* *}$ \\
Cum-Res & & & & & & & & 1 \\
\hline
\end{tabular}

Micro Q- Microbial quotients; Meta Q - metabolic quotient; qM - carbon mineralization quotient; qC- Microbial biomass change rate quotient ;MBC- microbial biomass carbon; OC- Organic carbon; Res- Soil respiration; Cum-Res- Cumulative soil respiration

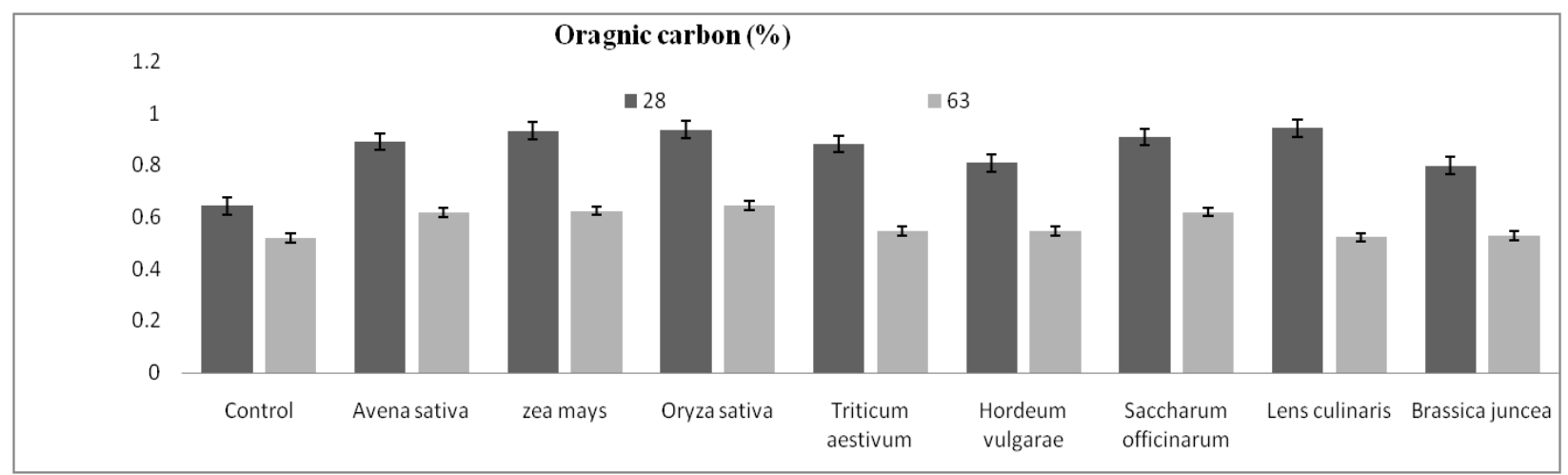

Fig.1. Organic carbon content (\%) at 28 and 63 days of incubation with application of different crop residues. Treatments are significantly different at $p<0.05$.

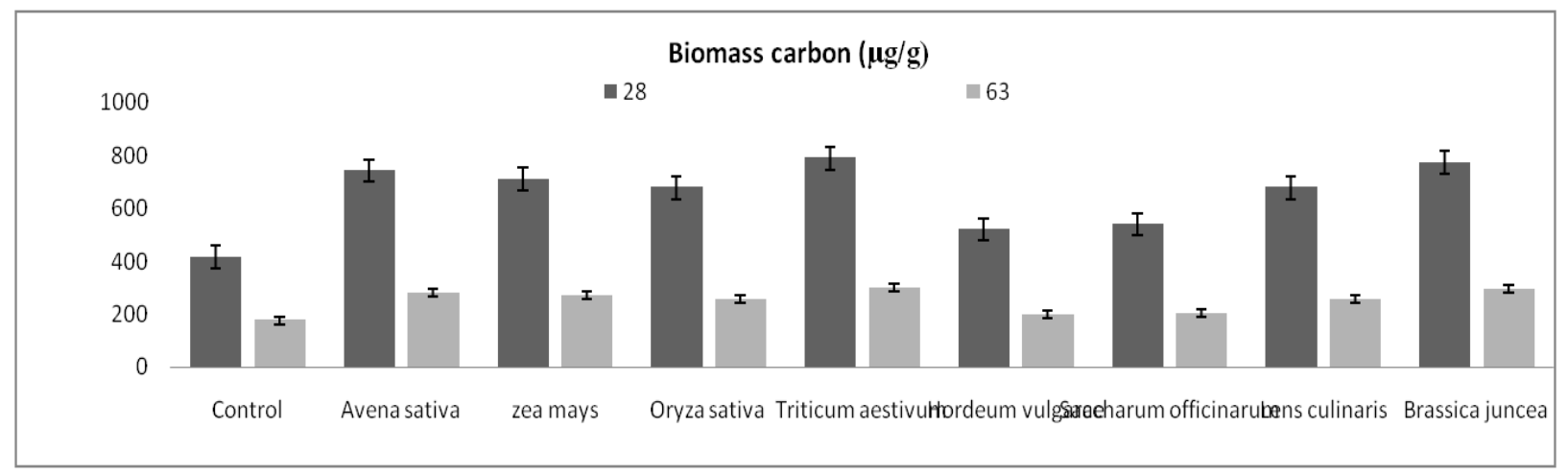

Fig. 2. Microbial biomass $C$ measured at 28 and 63 days of incubation with application of different crop residues. Treatments are significantly different at $\quad p<0.05$. 


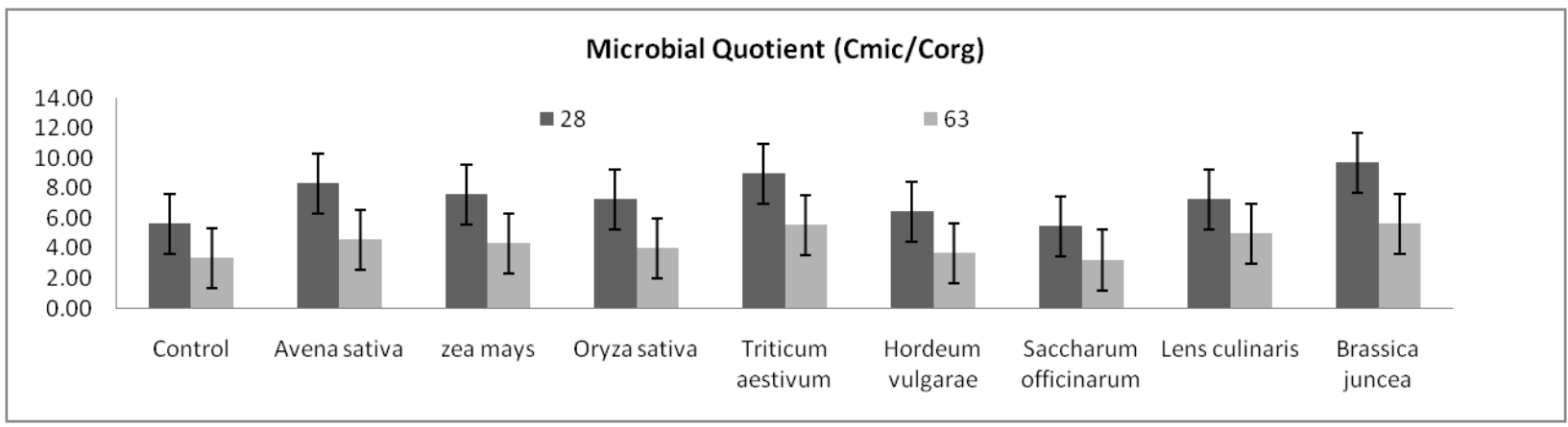

Fig. 3. Microbial quotient at 28 and 63 days of incubation with application of different crop residues. Treatments are significantly differentat $p<0.05$.

\section{Metabolic quotient ( $\mu \mathrm{gg}-\mathrm{CO}_{2} / \mathrm{h} / \mu \mathrm{gC}$ biomass)}

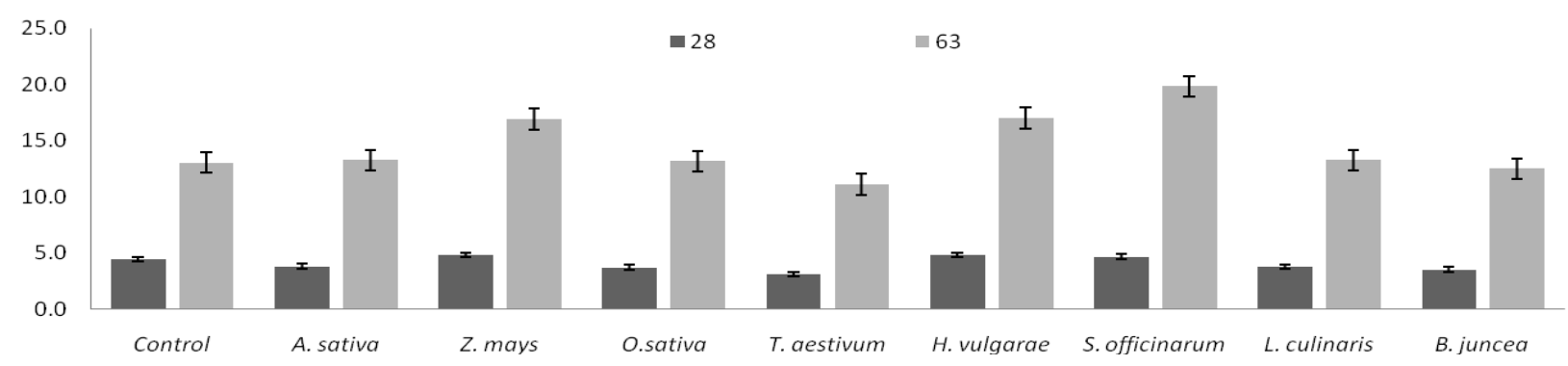

Fig. 4. Metabolic quotient at 28 and 63 days of incubation with application of different crop residues. Treatments are significantly differentat $p<0.05$.

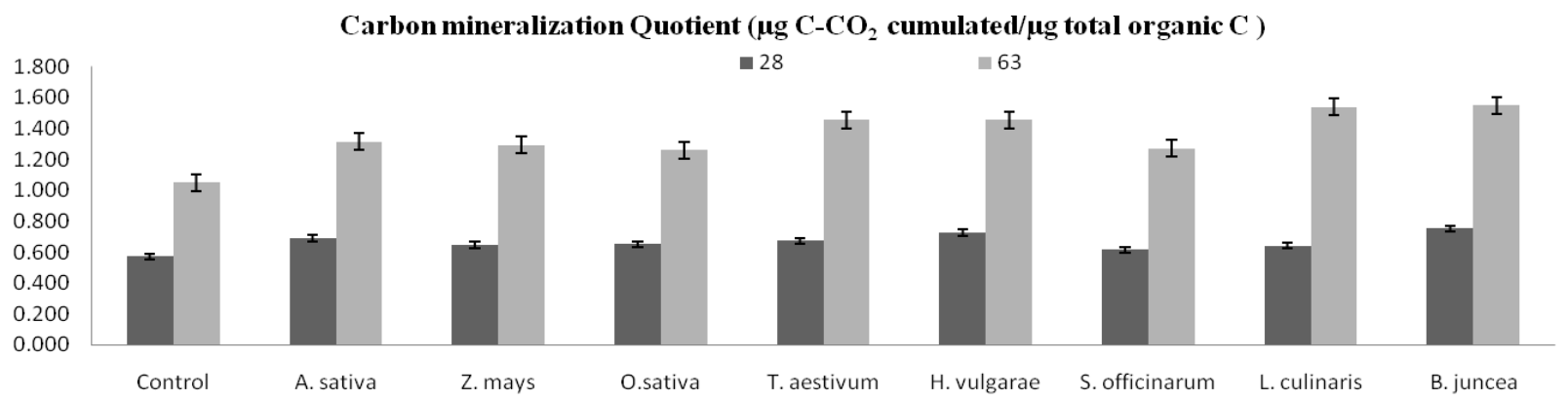

Fig. 5. Carbon mineralization quotient at 28 and 63 days of incubation with application of different crop residues. Treatments are significantly differentat $p<0.05$.

\section{Microbial biomass change rate quotient}

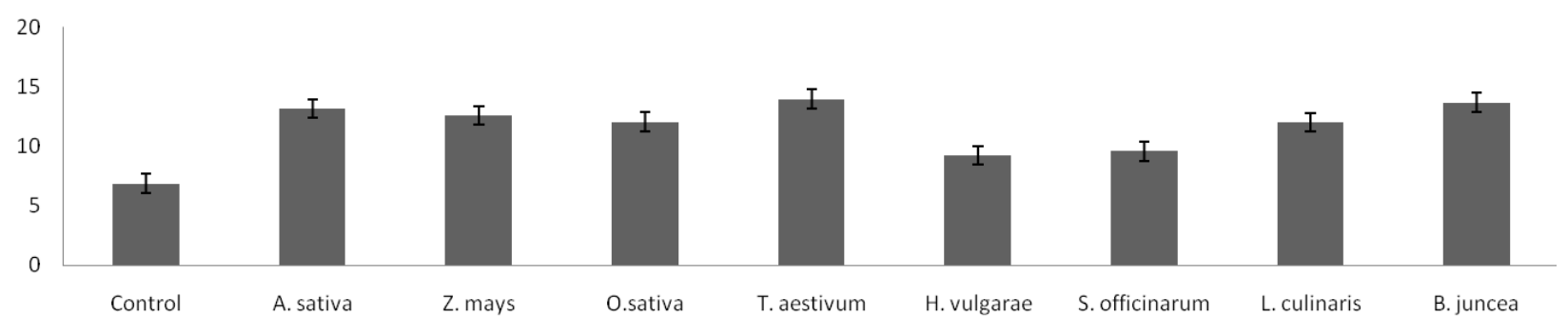

Fig. 6. Microbial biomass change rate quotient $(q C)\left(\left(\mu g\right.\right.$ Cmict $_{1}-\mu g C$ mic $\left.t_{2}\right) / \mu g$ Cmict1 $\left./\left(t_{2}-t_{1}\right)\right) X 10^{-3}$ in different crop residues and control plots after 35 days. Treatments are significantly different at $p<0.05$.

treatment, regardless of the residue type, biochemical quality and composition.

Soil organic carbon: Different crop residues significantly increased the soil organic carbon content at 28 days and 63 days after incubation is given in fig. 1. Soil organic carbon content ranged from 0.643 to $0.937 \%$ at $28 \mathrm{DAI}$ and 0.519 to $0.644 \%$ at $63 \mathrm{DAI}$. The organic carbon content increased in both stages, but was higher 
increase in $O$. sativa followed by $Z$. mays and minimum in unamended plot.

Soil microbial biomass carbon: Effect of addition of crop residue on soil microbial carbon was observed on day 28 and 63 , of which maximum activity was observed on day 28 in the soil amended with T. aestivum residue while the minimum was observed in the unamended soil (Fig. 2). Thereafter, the decreased value was observed on day 63. Soil microbial biomass $\mathrm{C}$ ranged from 417 to $790 \mu \mathrm{g} / \mathrm{g}$. Microbial biomass significantly differed among different species of crop residues. On day 28, statistically significant difference was found between the amended and unamended soil. Similar trend was observed on day 63.

Soil microbial indices: Microbial quotient (Cmic:Corg) differed significantly among the different species of plant residue (Fig. 3). The microbial quotient among different crop residues ranged from 5.62 to 9.69 and 3.35 to 5.64 at 28 and 63 DAI, respectively. Among different crop residues, B. juncea showed significantly higher microbial quotient followed by $T$. aestivum. The metabolic quotient $\left(\mathrm{qCO}_{2}\right)$ did not differ among the residues at 28 DAI, whereas amended residues had high values as compared to unamended on day 63 (Fig. 4). The metabolic quotient among different crop residues ranged from 11.1 to $19.8 \mu \mathrm{g} \mathrm{CO}-\mathrm{C} \mu \mathrm{g}$-biomass- $\mathrm{C}^{-1} \mathrm{~h}^{-1}$ at 63 DAI, respectively, of which $S$. officinarum, $H$. vulgarae and $Z$. mays showed highest activity.

The qM provides information on the fraction of total organic carbon mineralized throughout the incubation time. The $\mathrm{qM}$ differed significantly among different crop residues ranged from 0.570 to 0.753 and 1.05 to $1.55 \mu \mathrm{g} \mathrm{C}-\mathrm{CO}_{2}$ cumulative $\mu \mathrm{g} \mathrm{TOC}^{-1}$ at 28 and $63 \mathrm{DAI}$, respectively (Fig. 5). Among different crop residues, $B$. juncea showed significantly higher $\mathrm{C}$ mineralization quotient followed by $L$. culinaris in comparison to other residues. The $\mathrm{qC}$ was measured in unamended and amended soil with different crop residues (Fig. 6). Microbial loss thus increased significantly under $T$. aestivum followed by $A$. sativa crop residue incorporation and minimum in unamended plot.

Relationship between organic carbon, soil microbial indices and microbial biomass $\mathrm{C}$ : Correlation between different microbial quotients, microbial biomass carbon and organic carbon are shown in tables 4 and 5 at 28 and 63 DAI, respectively. Microbial quotient was significantly and positively correlated with $\mathrm{qC}, \mathrm{qM}$ and $\mathrm{MBC}$. The values of correlation coefficient (r) for microbial quotients ranged from $0.700 * *$ to $0.910 * *$. Organic carbon content after 28 days was significantly related with cumulative respiration only. Metabolic quotients were negative correlation with all microbial indices.

\section{DISCUSSION}

Soil respiration: The $\mathrm{C}$ mineralization was strongly dependent on the initial chemical composition, which confirmed the findings of numerous studies on annual crops and perennial crops from natural ecosystems (Jensen et al., 2005). Soil respiration (Cmic) is the production of $\mathrm{CO}_{2}$ by metabolizing organisms within the soil matrix. It estimates the overall biological activity in the litter-soil layer and is known to be affected by availability of substrate, nutrients, moisture and temperature (Orchard and Cook, 1983; Alvarez et al., 1995). The addition of amendment in the present study resulted in an increase in soil respiration throughout the experiment in amended soil with maximum activity shown by $A$. sativa on $7^{\text {th }}$ day $\left(14.23 \mathrm{mg} \mathrm{CO}_{2}-\mathrm{C} \mathrm{g}^{-1}\right.$ soil day $\left.^{-1}\right)$. As the amount of crop residues was same, thus the rate of decomposition and availability of substrate could be the reason for the observed differences in respiration rates. An interesting trend of flush of $\mathrm{CO}_{2}$ in the initial stages followed by decrease in soil respiration rate with increase in incubation period was in accordance with the observation of Sánchez -Monedero et al., (2008). The increase in soil respiration rate is expected as easily degradable substrates are added to the soil. Organic matter addition sustained microbial growth for 14 days. It further suggested that substrate use efficiency increased with proceeding decomposition (Atlas and Bartha, 1998). Decreasing respiration in soil under constant conditions may be attributed to nutrient depletion in organic fractions and increasing dominance of recalcitrant molecules (Neely et al., 1991). Residue addition increased the respiration compared to the control with greatest increases observed on addition of $L$. culinaris and A. sativa which had lower carbon to nitrogen content. Higher $\mathrm{C}: \mathrm{N}$ ratio as obtained in other crop residues, leads to slow decomposition rate and thus reduced $\mathrm{CO}_{2}$ emission (Henderson et al ., 2010). The cumulative soil $\mathrm{CO}_{2}$ efflux through soil respiration in amended soil was also found to be higher than unamended soil. This pattern supports our hypothesis that the activity of various crop residues is due to different $\mathrm{C} / \mathrm{N}$ ratio, showing different decomposition rates. These results can be attributed to the presence of higher cellulose and hemicellulose contents but also to low $\mathrm{N}$ content (total and soluble) combined with limited $\mathrm{N}$ availability in the soil effect $\mathrm{C}$ mineralization and plant residue decomposition (Abiven et al., 2005; Thippayarugs et al., 2008).

Soil microbial biomass carbon: Soil microbial biomass is an important ecological indicator and acts as a source and sink of available nutrient for plant growth. Little change in soil microbial biomass affects directly on ecosystem stability and fertility of soil. Therefore microbiological status is considered as a suitable indicator of soil health during restoration process of degraded agroecosystems (Haripal and Sahoo, 2014). Our results showed that different crop residue decompose at different rates and, therefore, the nutrients present in them were released at different times. These differences in organic matter decomposition 
rates are influenced by the chemical composition of the crop residues. The activity of $\mathrm{MBC}$ is stimulated by an increase in available carbon (De Nobili et al., 2001) either from residues or root exudates from the plant roots and environmental conditions such as moisture and temperature (Lavelle and Spain, 2002). An overall increase in microbial biomass was observed on $28^{\text {th }}$ day. Eventually a decreasing trend was observed on $63^{\text {rd }}$ day. . This could be explained by the depletion of soluble carbohydrates and accumulation of recalcitrant compounds like polyphenols, which could inhibit microbial growth (Sall et al., 2003). Our studies showed that $T$. aestivum residues supported higher MBC $(790 \mu \mathrm{g} / \mathrm{g})$ than other crop residues as they have high carbon content $(42.0 \%)$ but low nitrogen content $(0.040 \%)$. Several studies have shown that C: N ratio has a primary effect on the net $\mathrm{N}$ mineralization from residues (Iritani and Arnold, 1960; Frankenberger and Abdelmagid, 1985; Constantinides and Fownes, 1994). Organic residues having low $\mathrm{C} / \mathrm{N}$ ratio show $\mathrm{N}$ mineralization more than those with wide $\mathrm{C} / \mathrm{N}$ ratio, with the latter mostly causing $\mathrm{N}$ immobilization during decomposition (Mary et al., 1996; Alexander, 1977)

Soil microbial indices: Microorganisms are the active component of soil organic matter and respond rapidly to the changes in the soil temperature, moisture content, crop residues (Rice et al., 1996). Different crop residues incorporation is an essential component with key multifunctional roles in soil quality and related to many physical and biological properties of soil (Smith et al., 2000). Some important parameters may also be derived from $\mathrm{MBC}$, such as Cmic:Corg (Insam and Domsch, 1988), and $\mathrm{qCO}_{2}$ (Insam and Haselwandter, 1989). Due to the quick response of microorganisms to the soil conditions, MBC could also be a good indicator of soil changes (Alvarez and Alvarez, 2000). The microbial quotient reflects the availability of $\mathrm{C}$ substrates for soil microorganisms (Anderson and Domsch, 1989). Llorente and Turrión (2010) used it as an indicator of environmental conditions adversity. The higher microbial quotient in B. juncea $\left(9.69 \mathrm{C}_{\mathrm{mic}}: \mathrm{C}_{\mathrm{org}}\right)$ followed by $T$. aestivum $\left(8.97 \mathrm{C}_{\text {mic }}: \mathrm{C}_{\text {org }}\right.$ ) than residues of other species indicates larger substrate availability to the soil microorganisms and a positive trend for organic $\mathrm{C}$ accumulation. The decaying litter constitutes the site of an active microbial pool because of the availability of ecophysiological maintenance carbon that serves as their energy source (Anderson and Domsch, 1985). It is known that the energy flux through the microbial biomass is the driving force for decomposition of residues and detritus materials (Smith and Paul, 1990) which is in agreement with our findings that the addition of residues enhances the microbial activity. Powlson et al. (1987) and Wardle (1992) pointed out that the $\mathrm{MBC}$ and $\mathrm{Cmic}$ :Corg can provide an effective early warning of the deterioration of soil quality. The $\mathrm{qCO}_{2}$ has valuable application as a relative measure of how efficiently the soil microbial biomass is utilizing
$\mathrm{C}$ resources and the degree of substrate limitation for soil microbes (Wardle and Ghani, 1995; Dilly and Munch, 1998). The $\mathrm{qCO}_{2}$ indicates the efficiency by which soil microorganisms use C-resources in the soil, and it is expected that stressed soils will provide higher $\mathrm{qCO}_{2}$ values than less-stressed soils. Nutrients acquisition activity is an energetically expensive process particularly when microbes are forced to degrade stable SOM to get new available substrates (Moscatelli et al., 2005). Organic matter additions are capable of either reducing or enhancing a soil's $\mathrm{qCO}_{2}$, depending on soil management (Van Antwerpen et al., 2003). The $\mathrm{qCO}_{2}$ significantly increased in soils amended with $S$. officinarum $\left(19.8 \mu \mathrm{g} \mathrm{CO}_{2}-\mathrm{C} \mu \mathrm{g}-\right.$ biomass- $\left.\mathrm{C}^{-1} \mathrm{~h}^{-1}\right)$, H. vulgarae $\left(17.0 \mu \mathrm{g} \quad \mathrm{CO}_{2}-\mathrm{C} \mu \mathrm{g}-\right.$ biomass- $\left.\mathrm{C}^{-1} \mathrm{~h}^{-1}\right)$ and $Z$. mays (16.9 $\mu \mathrm{g} \mathrm{CO} \mathrm{CO}_{2}-\mathrm{C} \mu \mathrm{g}-$ biomass $-\mathrm{C}^{-1} \mathrm{~h}^{-1}$ ) on $63^{\text {rd }}$ day of incubation suggesting less efficient microbial utilization of $\mathrm{C}$ in these cases. Soil treated with $T$. aestivum showed the lowest $\mathrm{qCO}_{2}$ among the organic-amended soils. This fact suggested that not only the amount of TOC added to the soil but also the quality of organic matter affected the $\mathrm{qCO}_{2}$. A possible explanation for the different response of the $T$. aestivum treatment, as compared to other crop residues could be the lower degradability of $T$. aestivum, and therefore the different pool of available C (De Nobili et al., 1984). Lundquist et al. (1999) also reported increase in $\mathrm{qCO}_{2}$ with organic matter additions. Our findings are in close agreement with the increase in the ratio of metabolic quotient with the addition of residues.

\section{Conclusion}

Microbial indices proved to be sensitive to changes occurring in soil processes due to addition of different crop residues having different chemical composition. An overall increase in microbial biomass and their activity was observed in amended soil as compared to unamended control. In addition, results obtained under laboratory conditions suggest that the decomposition of crop residues having different chemical composition can be fairly predicted from the initial chemical components of the residues. Therefore, addition of organic matter to soil can maintain the ecological balance of microflora and may also help in enhancement of biological status of soil. The microbial (Cmic: Corg), metabolic $\left(\mathrm{qCO}_{2}\right)$, carbon mineralization $(\mathrm{qC})$ and microbial biomass change rate (qM) quotients, all seem to be suitable diagnostic indicator of the quality of the soil.

\section{REFERENCES}

Abiven, S., Recous, S., Reyes, V. and Oliver, R. (2005). Mineralisation of $\mathrm{C}$ and $\mathrm{N}$ from root, stem and leaf residues in soil and role of their biochemical quality. Biology and Fertility of Soils, 42: 119-129.

Alef, K. (1995). Basal respiration. In: Method in Applied Soil Microbiology and Biochemistry. (Eds K Alef, P Nannipieri). Academic Press: Harcourt Brace and 
Company. Londo) pp. 228-231.

Alexander, M. (1977). Introduction to Soil Microbiology. Second edition. USA, Canada, John Willey \& Sons: 467.

Alvarez, C.R. and Alvarez, R. (2000). Short term effects of tillage systems on active soil microbial biomass. Biology and Fertility of Soils, 31: 157-161.

Alvarez, R., Santanotoglia, O.J. and Garcia, R. (1995). Effect of temperature on soil microbial biomass and its metabolic quotient in site under different tillage systems. Biology and Fertility of Soils, 19: 227-230.

Anderson, J.P.E (1982) Soil respiration. In A.L. Page et at. (ed.) Methods of soil analysis, Part 2. Chemical and Microbiological Properties (2nd eds). Amercian Society of Agronomy. Madison, Wisconsin USA pp. 831-871.

Anderson, T.H. and Domsch, K.H. (1985). Determination of ecophysiological maintenance carbon requirements of soil microorganisms in a dormant state. Biology and Fertility of Soils, 1: 81-89.

Anderson, T.H. and Domsch, K.H. (1989). Ratios of microbial biomass carbon to total organic-C in arable soils. Soil Biology and Biochemistry, 21: 471-479.

Anderson, T.H. and Domsch, K.H. (1990). Application of eco-physiological quotients (qCO2 and $\mathrm{qD}$ ) on microbial biomasses from soils of different cropping histories. Soil Biology and Biochemistry, 22: 251-255.

Atlas, R.M. and Bartha, R. (1998). Microbial Ecology: Fundamentals and applications 4th Edition. Benjamin cummings publishing company Inc. Addison Wesley Longman Inc. pp. 300-350

Badia, D. and Marti, C. (2003). Effect of simulated fire on organic matter and selected micro biological properties of two contrasting soils. Arid Land Research and Management, 17: 55 - 70.

Bini, D., Santos, C., Carmo, B., Kishino, N., Andrade,G., Waldemar, Z. and Nogueira, M. A. (2013). Effects of land use on soil organic carbon and microbial processes associated with soil health in southern Brazil. European Journal of Soil Biology 55: 117-123.

Bouajila, K. and Sanaa, M. (2011). Effects of organic amendments on soil physico-chemical and biological properties Journal of Material and Environmental Science, 2: 485-490

Brookes, P.C. (1995). The use of microbial parameters in monitoring soil pollution by heavy metals. Biology and Fertility of Soils, 19: 269-279.

Campbell, C.A. Moulin, A.P. Bowren, K.E. Janzen, H.H. Townly-Smith, L. and Biederbeck, V.O. (1992). Effect of crop rotation on microbial biomass, specific respiratory activity and mineralizable nitrogen in a Black Chernozemic soil. Canadian Journal of Soil Science, 72: 417-427.

Constantinides, M. and Fownes, J.H. (1994). Nitrogen mineralization from leaves and litter of tropical plants: relationships to nitrogen, lignin and soluble polyphenol concentrations. Soil Biology and Biochemistry, 26: 49-55.

De Nobili, M., Cercignani, G., Leita, L. (1984). Evaluation of type and contents of humic substances in sludges and composts. In: Williams JH, Guidi G, L'Hermite P (eds) Long-term effects of sewage sludge and farm slurry applications. Elsevier, London, pp 204-209.

De Nobili, M., Contin, M., Mondini, C. and Brookes, P.C. (2001). Soil microbial biomass is triggered into activity by trace amounts of substrate. Soil Biology and Biochemistry, 33: 1163-1170.
Dilly, O. and Munch, J.C. (1998). Ratios between estimates of microbial biomass content and microbial activity in soils. Biology and Fertility of Soils, 27: 374-379.

Frankenberger, W.T. and Abdelmagid, H.M. (1985). Kinetic parameters of nitrogen mineralisation rate of leguminous crops incorporated into soil. Plant and Soil, 87: 257 -271 .

Haripal, K. and Sahoo, S.(2014). Microbial biomass Carbon, Nitrogen, and Phosphorus dynamics along a chronosequence of abandoned tropical agroecosystems. International Journal of Current Microbiology and Applied Sciences, 3: 956-970

Heal, O.W., Anderson, J.M. and Swift, M.J. (1997). Plant litter quality and decomposition: an historical overview. In: Cadisch $G$ \& Giller KE (Eds) Driven by Nature - Plant Litter Quality and Decomposition, CAB International, Wallingford pp 3-30.

Henderson, S.L., Dandie, C.E., Patten, C.L., Zebarth, B.J., Burton, D.L., Trevors, J.T. and Goyer, C. (2010). Changes in denitrifier abundance, denitrification gene mRNA levels, nitrous oxide emissions, and denitrification in anoxic soil microcosms amended with glucose and plant residues. Applied Environmental Microbiology, 76: $2155-2164$.

Insam, H. and Domsch, K.H. (1988). Relationship between soil organic carbon and microbial biomass on chronosequences of reclamation sites. Microbial Ecology, 15: 177-188.

Insam, H. and Haselwandter, K. (1989). Metabolic quotient of the soil microflora in relation to plant succession. Oecologia, 79: 174-178.

Iritani, W.M. and Arnold, C.Y. (1960). Nitrogen release of vegetable crop residues during incubation as related to their chemical composition. Soil Science, 9: 74-82.

Jensen, L.S, Salo, T., Palmason, F., Breland, T.A., Henriksen, T.M., Stenberg, B., Pedersen, A., Lundström, C. and Esala, M. (2005). Influence of biochemical quality on $\mathrm{C}$ and $\mathrm{N}$ mineralisation from a broad variety of plant materials in soil. Plant and Soil, 273: 307-326.

Lavelle, P. and Spain, A.V. (2002). Soil Ecology. Kluwer Academic Publisher, The Netherlands.

Lehtinen, T., Schlatter, N., Baumgarten, A., Bechini, L., Krüger, J., Grignani, C., Zavattaro, L., Costamagna, C. and Spiegel, H. (2014). Effect of crop residue incorporation on soil organic carbon and greenhouse gas emissions in European agricultural soils. Soil Use and Management, 30: 524-538.

Llorente, M. and Turrión, M. (2010). Microbiological parameters as indicators of soil organic carbon dynamics in relation to different land use management. European Journal of Forest Research, 129: 73-81.

Lundquist, E.J, Jackson, L.E., Scow, K.M. and Hsu, C. (1999). Changes in microbial biomass and community composition, and soil carbon and nitrogen pools after incorporation of rye into three California agricultural soils. Soil Biology and Biochemistry, 31: 221-236.

Mary, B., Recous, S., Darwis, D. and Robin, D. (1996). Inter -actions between decomposition of plant residues and nitrogen cycling in soil. Plant and Soil, 181: 71-82.

Mengel, K. (1996). Turnover in soil and its availability of crops. Plant and Soil, 181: 83-93.

Moscatelli, M.C., Lagomarsino, A., Marinari, S., De Angelis, P., Grego, S. (2005). Soil microbial indices as bioindicators of environmental changes in a poplar 
plantation. Ecological Indicator, 5: 171-179

Neely, C.L., Beare, M.H., Hargrove, W.L. and Coleman, D.C. (1991). Relationships between fungal and bacterial substrate-induced respiration, biomass, and plant residue decomposition. Soil Biology and Biochemistry, 23: 947-954.

Olsen, S.R., Cole, C.V., Watanabe, F.S. and Dean, I.A. (1954) Estimation of available phosphorus in soils by extraction with sodium bicarbonate, U.S. Department of Agriculture Cirle. 939: 1-19.

Orchard, V.A and Cook F.J. (1983). Relationship between soil respiration and soil moisture. Soil Biology and Biochemistry, 15: 447-453.

Pandiaraj, T., Selvaraj, S. and Ramu, N. (2015). Effects of Crop Residue Management and Nitrogen Fertilizer on Soil Nitrogen and Carbon Content and Productivity of Wheat (Triticum aestivum L.) in Two Cropping Systems. Journal of Agricultural Science and Technology, 17: $249-260$

Pinzari, F., Trinchera, A., Benedetti, A. and Sequi, P. (1999). Use of biochemical indices in the Mediterranean environment: comparison among soils under different forest vegetation. Journal of Microbiololgy and Methods, 36: 21-28.

Powlson, D.S., Brookes, P.C. and Jenkinson, D.S. (1987). Measurement of soil microbial biomass provides an early indication of changes in total soil organic matter due to straw incorporation. Soil Biology and Biochemistry, 19: $159-164$.

Rice, C.W., Moorman B.T. and Beare M. (1996) Role of Microbial Biomass Carbon and Nitrogen in Soil Quality. V: Methods for Assessing Soil Quality. Doran W.J.in Jones A.L. (ur.) Madison, Wisconsion USA, Soil Science Society of America pp 144-173.

Sall, S.N., Masse D., Bernhard-Reversat F., Guisse A. and Chotte J.L. (2003). Microbial activities during the early stage of laboratory decomposition of tropical leaf litters: The effect of interactions between litter quality and exogenous inorganic nitrogen. Biology and Fertility of Soils, 39: 103-111.

Sánchez-Monedero, M.A., Mondini, C., Cayuela, M.L., Roig, A., Contin, M. and De Nobili, M. (2008). Fluorescein diacetate hydrolysis, respiration and microbial biomass in freshly amended soils. Biology and Fertility of Soils, 44:885-890.

Santruckova, H. and Straskraba, M. (1991). On the relationship between specific respiration activity and microbial biomass in soils. Soil Biology and Biochemistry, 23: 525-532.
Saviozzi, Y.A., Bufalino, P.. Levi-Minzi, R. and Riffald, R. (2002). Biochemical activities in a degraded soil restored by two amendments: a laboratory study. Biology and Fertility of Soils, 35 96-101.

Smith, J.L and Paul, E.A. (1990). The significance of soil biomass estimations. Soil Biochemistry 6 eds (Bolag JM and Stotzky G) Marcel Dekker, New York pp 357-396.

Smith, K.A., Dobbie, K.E., Ball, B.C., Bakken, L.R., Sitaula, B.K, Hansen, S.R., Brumme, R., Borken, W., Christensen, S., Priemé, A., Fowler, D., Macdonald, J.A., Skiba, U., Klemedtsson, L., Kasimir-Klemedtsson, A., Degórska, A. and Orlanski, P. (2000), Oxidation of atmospheric methane in Northern European soils, comparison with other ecosystems, and uncertainties in the global terrestrial sink. Global Change Biology, 6: 791-803.

Sparling, G.P. and Ross, D.J. (1993). Biochemical methods to estimate soil microbial biomass: current developments and applications. In: Mulongy K, Merckx R (eds) Soil organic matter dynamics and sustainability of tropical agriculture. Wiley-Sayce Co-Publication, IITA/K.U, Leuven, The Netherlands, pp 21-37.

Subbiah, B.V. and Asija, G.L. (1956). A rapid procedure for estimation of available nitrogen in soils. Current Science, 25: 259-260.

Thippayarugs, S., Toomsan, B., Vityakon, P., Limpinuntana, V., Pananothai, A. and Cadish, G. (2008). Interactions in decomposition and mineralization between tropical legume residue components. Agroforestry Systems, 72: 137-148.

Van Antwerpen, R., Haynes, R., Meyer, J.H. and Hlanze, D. (2003). Assessing organic amendments used by sugarcane growers for improving soil chemical and biological properties. Proceeding of South Afercian Sugur Technologists Association, 77: 293-299.

Vance, E.D., Brookes, P.C. and Jenkinson, D.S. (1987). An extraction method for measuring soil microbial biomass C. Soil Biology and Biochemistry, 19: 703-707.

Walkley, A. and Black, I.A. (1934). An examination of the degtjareff method for determining soil organic matter and a proposed modification of the chromic acid titration method. Soil Science, 37: 29-38.

Wardle, D.A. (1992). A comparative assessment of factors which influence microbial biomass carbon and nitrogen levels in soils. Biological Reviews, 67: 321-358.

Wardle, D.A. and Ghani, A. (1995). A critique of the microbial metabolic quotient $\left(\mathrm{qCO}_{2}\right)$ as a bioindicator of disturbance and ecosystem development. Soil Biology and Biochemistry, 27: $1601-1610$. 